\title{
A STUDY ON DETECTING HEAVY METAL ACCUMULATION THROUGH BIOMONITORING: CONTENT OF TRACE ELEMENTS IN PLANTS AT MOUNT KAZDAGI IN TURKEY
}

\author{
DOGAN, Y. ${ }^{1}-$ BASLAR, $S .{ }^{1}-$ UGULU, I. ${ }^{2 *}$ \\ ${ }^{I}$ Department of Biology, Buca Faculty of Education, Dokuz Eylul University, \\ Izmir, Turkey \\ ${ }^{2}$ Department of Biology, Necatibey Faculty of Education, Balikesir University, \\ Balikesir, Turkey \\ (phone: +90266 2412762-52; fax: +90 266 2495005) \\ *Corresponding author \\ e-mail:ilkerugulu@mynet.com \\ (Received $1^{\text {st }}$ March 2011; accepted $22^{\text {nd }}$ July 2014)
}

\begin{abstract}
The purpose of this study is to determine the present levels of atmospheric heavy metal pollution in the area of the Kazdagi Mountain in the Aegean region in the western part of Turkey. Twenty-five different plants were selected as potential biomonitors of trace elements including nickel, iron, zinc, lead, cadmium, and manganese ( $\mu \mathrm{g} \mathrm{g}^{-1}$, dry weight). The samples were collected from two different heights of Mt. Kazdagi. Atomic absorption spectrometry was used to determine the concentrations of trace elements. The mean concentrations determined at $600 \mathrm{~m}$ altitude ranged from 0.107 to $0.442,0.269$ to $0.619,0.873$ to $9.030,0.338$ to 0.523 and 0.143 to 2.823 ( $\mu \mathrm{g} \mathrm{g}^{-1}$, dry weight), for $\mathrm{Ni}, \mathrm{Zn}, \mathrm{Fe}, \mathrm{Pb}$ and $\mathrm{Mn}$, respectively. At $1100 \mathrm{~m}$ altitude, the values ranged from 0.119 to $1.806,0.232$ to $0.792,0.618$ to $5.720,0.371$ to 0.534 and 0.766 to 4.782 ( $\mu \mathrm{g} \mathrm{g}^{-1}$, dry weight) for $\mathrm{Ni}, \mathrm{Zn}, \mathrm{Fe}, \mathrm{Pb}$ and $\mathrm{Mn}$, respectively. No Cd was found at either altitude. For the determination of the existence of any differences between the averages of the herbaceous and woody plants, comparisons were made in the independent sample $t$-test. In the statistical analysis, comparison of heavy metal pollution values of herbaceous and woody plants for $\mathrm{Ni}, \mathrm{Fe}$ and $\mathrm{Mn}$ was significant $(P<0.05)$, while it was not for $\mathrm{Pb}$ and $\mathrm{Zn}$.
\end{abstract}

Keywords: Mt. Kazdagi, biomonitoring, trace element

\section{Introduction}

Increasing anthropogenic influences on the environment have caused negative changes in natural ecosystems and altered the normal biogeochemical cycling (Ugulu et al., 2008; Dogan, 2012; Ugulu, 2012; Dogan et al., 2013). Among the anthropogenic activities, heavy metal contamination of the biosphere has increased sharply since 1900 and it poses major environmental and human health problems worldwide (Prasad \& Freitas, 2003). The circulation and migration of metals in the natural environment are mainly related to such processes as rock decay, volcanic eruptions, evaporation of oceans, forest fires and soil formation. The sources of anthropogenic contamination or pollution of the environment by heavy metals include different branches of industry such as the power industry, transport, municipal waste management, waste dumping sites, fertilisers and waste used to fertilise soil (Aksoy et al., 2000; Karaca et al., 2005; Osma et al., 2012). The heavy metals from these sources are dispersed in the environment and they contaminate soil, water and air (Elekes et al., 2010). They also get into human and animal bodies, directly or indirectly, through plants (Szyczewski, 2009; Yasar et al, 2012a).

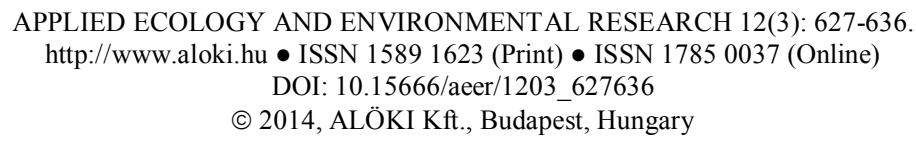


Biological monitoring within a quality control programme involves the systematic use of living beings for obtaining quantitative information on changes in the environment, often due to anthropogenic activities (Bargagli, 1998). Biological responses can be considered more representative than data supplied by chemical or physical detectors, in that they are spatially and temporally extensive; moreover, they allow for estimating both the levels of pollutants and, even more importantly, the impact on biological receptors (Calzoni et al., 2007). For this reason, in order to evaluate, minimise and avoid detrimental effects of toxic metals, there has been an emphasis on the use of natural bioindicators to monitor atmospheric quality in both urban and rural environments (Szczepaniak \& Biziuk, 2003; Ng et al., 2005).

Biomonitoring has been used to detect the deposition, accumulation and distribution of trace metals in the ecosystems. By using different types of vegetation with this method, the levels of atmospheric trace metallic concentrations have been successfully monitored (El-Hasan et al., 2002; Baslar et al., 2003; Dogan et al., 2007; Onder et al., 2007). Biomonitoring provides the cheapest and simplest method for monitoring trace metals elements in the atmosphere (Kaya \& Yaman, 2008; Cayir et al., 2008).

Recently, many studies have been devoted to showing the distribution of heavy metal pollution in the urban and ruderal habitats in Turkey (Baslar et al., 2005; Yilmaz et al., 2006; Dogan et al., 2007; Cayir et al., 2008; Ozturk et al., 2008; Huseyinova et al., 2009; Akguc et al., 2010; Durkan et al., 2011; Ugulu et al., 2012; Yasar et al., 2012b). In some of these studies, mountainous areas, assumed to be unpolluted, have been used as control groups (i.e. Baslar et al., 2003, 2005, 2009; Yilmaz \& Zengin, 2004; Dogan et al., 2007; Dogan et al., 2010). The present study is significant in that it aims to determine heavy metal levels in mountainous areas which are considered to be free of heavy metals, and, therefore, uses them as a reference.

The purpose of this study was to investigate and present the concentrations of lead, cadmium, nickel, zinc, iron and manganese by using plant samples from Mt. Kazdagi.

\section{Materials and methods}

\section{Sampling area}

Mt. Kazdagi (Mt. Ida) is the highest mountain on the Biga Peninsula, which is situated in the south-western part of Anatolia (Fig.1). It separates the Aegean and Marmara regions. It has three summits and the highest among them is $1774 \mathrm{~m}$. Mt. Kazdagi possesses various climatic features due to its geographical position. On its south slopes, it is possible to see the characteristic Mediterranean climate because of its proximity to the Aegean Sea, whereas a cooler and more humid terrestrial climate is observed on its northern slopes.

Because of its climatic properties, geological structure and location, Mt. Kazdagi is ecologically and floristically diverse, containing a number of plant species endemic to Turkey. There are about 800 taxa growing naturally in the area and 79 of them are endemic to Turkey (Satil, 2008).

The location of the sampling points on steep slopes provides results that depend on altitude rather than on horizontal distance (Zechmeister, 1995). The samples were collected from altitudes of $600 \mathrm{~m}$ and $1100 \mathrm{~m}$ above sea level and 35-40 km away from the city centre. 


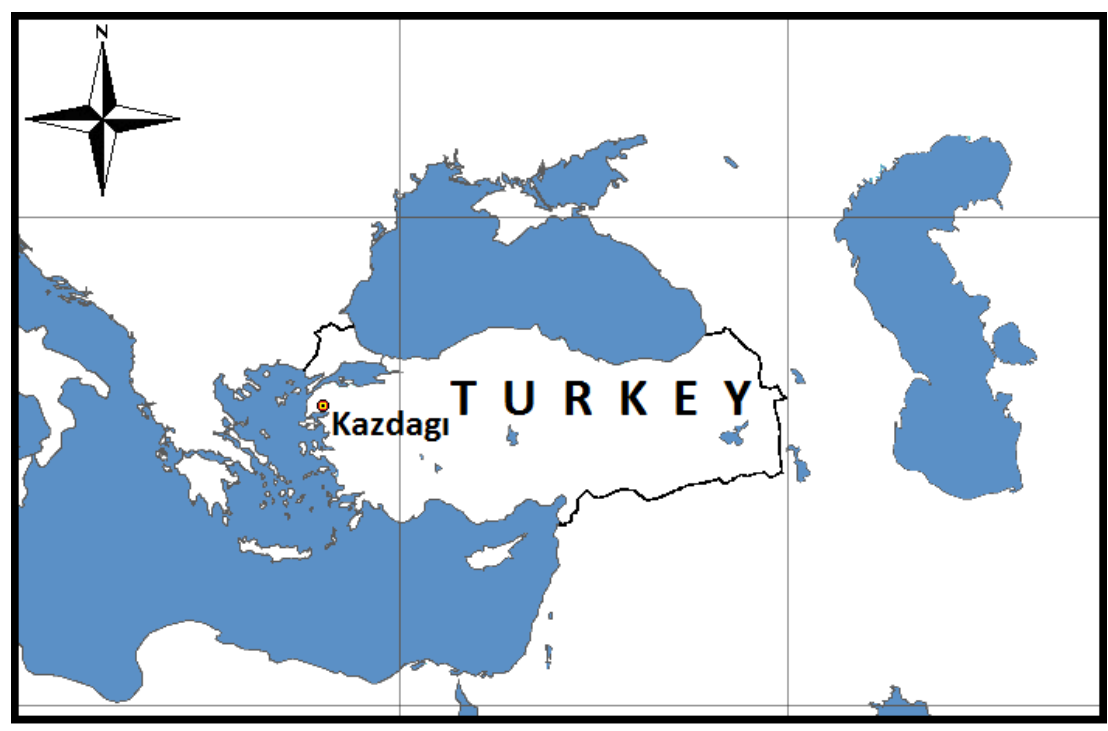

Figure 1. Geographical location of the study area

\section{Sample collection and preparation}

The samples were collected from $600 \mathrm{~m}$ and $1100 \mathrm{~m}$ during the months of JulyAugust, 2006. Twenty-five plant species in total were collected, 11 of which were from $600 \mathrm{~m}$ and 14 from $1100 \mathrm{~m}$. The taxonomy of the plant samples was determined according to Davis (1965-1985), Davis et al. (1988) and Guner et al. (2001).

For analysis purposes, about $100 \mathrm{~g}$ of aboveground parts of bushy species and welldeveloped leaves of other plants were collected. The samples were dried in an oven at $80^{\circ} \mathrm{C}$ for $24 \mathrm{~h}$, milled in a micro-hammer cutter and fed through a $0.2 \mathrm{~mm}$ sieve. The samples were stored in clean self-sealing plastic bags under silica gel desiccant. In order to eliminate contamination from the micro-hammer cutter during the grinding, it was washed after every grinding, first with absolute alcohol then with distilled water. Therefore, the contamination was negligible.

\section{Wet digestion procedure}

The method described by the Perkin Elmer Corporation was used for plant digestion (Anonymous, 1996). The digested samples were aspirated into an air-acetylene flame and the existence of metals was determined by flame atomic absorption spectrometry (FAAS). The reproducibility was ensured by carrying out triplicate analyses. All samples were analysed immediately after digestion.

\section{Reagents}

Unless otherwise specified, all the chemicals used were of analytical reagent grade. Triple-distilled water was used throughout the experiments. By diluting the stock standard solution with water, working metal standard solutions were prepared just before use.

\section{Instrumentation}

The existence of the metals was determined with the Perkin Elmer Analyst 700 model flame atomic absorption spectrometer equipped with deuterium background 
correction, hollow cathode lamps (HCL) and acetylene burner. The absorption measurements of the metals were performed under the conditions recommended by the manufacturer. A Cole-Parmer microfiltration apparatus with membrane filter $(0.45 \mu \mathrm{m}$ pore size manufactured by Micro Filtration Systems, MFS) was used for the filtration of the aqueous phase before metal determination.

\section{Data analysis}

Statistical significance was determined by the independent sample $t$-test. In the independent sample $\mathrm{t}$ - test, comparisons were made in order to determine whether there were any differences between the averages of the herbaceous plants and woody plants. Differences at $P<0.05$ were considered to be significant. A statistical package was used in the analysis of $t$-test for the data collected.

\section{Results and discussion}

The plants, used as biomonitors to investigate the levels of the trace elements, were sampled with 25 different species at two different levels of altitude on Mt. Kazdagi. The concentrations of elements were determined by atomic absorption spectrometry. The levels of the trace elements $\mathrm{Cd}, \mathrm{Ni}, \mathrm{Zn}, \mathrm{Fe}, \mathrm{Pb}$ and $\mathrm{Mn}\left(\mu \mathrm{g} \mathrm{g}{ }^{-1}\right.$, dry weight) in plant samples from different altitudes of Mt. Kazdagi are given in Tables 1 and 2. As a result of experiments carried out, the following mean concentrations were determined for 600 $\mathrm{m}$ altitude: The contents of $\mathrm{Ni}, \mathrm{Zn}, \mathrm{Fe}, \mathrm{Pb}$ and $\mathrm{Mn}\left(\mu \mathrm{g} \mathrm{g}^{-1}\right.$, dry weight) ranged from 0.107 to $0.442,0.269$ to $0.619,0.873$ to $9.030,0.338$ to 0.523 and 0.143 to 2.823 , respectively (Table 1). As for the average for $1100 \mathrm{~m}$ altitude, the contents of $\mathrm{Ni}, \mathrm{Zn}$, $\mathrm{Fe}, \mathrm{Pb}$ and $\mathrm{Mn}\left(\mu \mathrm{g} \mathrm{g}^{-1}\right.$, dry weight) ranged from 0.119 to $1.806,0.232$ to $0.792,0.618$ to $5.720,0.371$ to 0.534 and 0.766 to 4.782 , respectively (Table 2). No Cd values were determined in the samples collected from both heights.

Table 1. Trace element contents in plants growing in the Mt. Kazdagi ( $\mu g g-1$ dry weight) (600m)

\begin{tabular}{|c|c|c|c|c|c|}
\hline Plant & $\mathbf{N i}$ & Zn & $\mathbf{F e}$ & $\mathbf{P b}$ & Mn \\
\hline \multicolumn{6}{|c|}{ woody } \\
\hline Celtis australis L. & 0.170 & 0.598 & 2.347 & 0.504 & 0.877 \\
\hline Cydonia oblanga Miller. & 0.138 & 0.521 & 1.432 & 0.523 & 0.226 \\
\hline Juglans regia L. & 0.222 & 0.619 & 2.633 & 0.357 & 0.531 \\
\hline Malus sylvestris Miller. & 0.134 & 0.414 & 1.449 & 0.503 & 0.230 \\
\hline Pinus brutia Ten. & 0.133 & 0.337 & 0.873 & 0.352 & 1.429 \\
\hline $\begin{array}{l}\text { Quercus cerris L. subsp. } \\
\text { cerris }\end{array}$ & 0.169 & 0.305 & 2.731 & 0.498 & 2.823 \\
\hline \multicolumn{6}{|c|}{ herbaceous } \\
\hline $\begin{array}{l}\text { Dryopteris filix-mas (L.) } \\
\text { Schott }\end{array}$ & 0.107 & 0.269 & 1.332 & 0.398 & 0.925 \\
\hline Epilobium angustifolium L. & 0.442 & 0.432 & 9.030 & 0.453 & 1.525 \\
\hline Hypericum lydium L. & 0.196 & 0.538 & 3.179 & 0.454 & 0.519 \\
\hline Juncus inflexus L. & 0.208 & 0.407 & 1.067 & 0.376 & 0.589 \\
\hline Verbascum sp. & 0.150 & 0.366 & 0.897 & 0.338 & 0.143 \\
\hline Min.: & 0.107 & 0.269 & 0.873 & 0.338 & 0.143 \\
\hline Max.: & 0.442 & 0.619 & 9.030 & 0.523 & 2.823 \\
\hline Mean: & $0.18 \pm 0.02$ & $0.43 \pm 0.03$ & $2.45 \pm 0.70$ & $0.43 \pm 0.02$ & $0.89 \pm 0.23$ \\
\hline
\end{tabular}


Some plant species are useful for biomonitoring of the atmospheric deposition of pollutants (Kaya \& Yaman 2008; Baycu et al., 2006; Mertens et al., 2005; Singh et al., 2005; Smodis et al., 2004). In this respect, the aggregation of investigated trace elements in plants collected from the $600 \mathrm{~m}$ height on Mt. Kazdagi was presented in Table 1. It can be seen from the table that $\mathrm{Ni}$ content was the highest in Epilobium angustifolium $\left(0.442 \mu \mathrm{g} \mathrm{g}^{-1}\right)$, and the lowest in Dryopteris filix-mas $\left(0.107 \mu \mathrm{g} \mathrm{g}^{-1}\right) . \mathrm{Zn}$ content was the highest in Juglans regia $\left(0.619 \mu \mathrm{g} \mathrm{g}^{-1}\right)$, and the lowest in Dryopteris filix-mas $\left(0.269 \mu \mathrm{g} \mathrm{g}^{-1}\right)$. It was determined that Fe content was the highest in Epilobium angustifolium $\left(9.030 \mu \mathrm{g} \mathrm{g}^{-1}\right)$, while the lowest was in Pinus brutia $\left(0.873 \mu \mathrm{g} \mathrm{g}^{-1}\right)$. In terms of $\mathrm{Pb}$ content, Cydonia oblanga $\left(0.523 \mu \mathrm{g} \mathrm{g}^{-1}\right)$ was the highest, and Verbascum sp. $\left(0.338 \mu \mathrm{g} \mathrm{g}^{-1}\right)$ was the lowest. Mn content was the highest in Quercus cerris subsp. cerris $\left(2.823 \mu \mathrm{g} \mathrm{g}^{-1}\right)$, and the lowest in Verbascum sp. $\left(0,143 \mu \mathrm{g} \mathrm{g}^{-1}\right)$. At $1000 \mathrm{~m}$, the highest values were recorded as $\mathrm{Ni}$ and $\mathrm{Fe}$ in Epilobium angustifolium, $\mathrm{Zn}$ in Juglans regia, $\mathrm{Pb}$ in Cydonia oblanga and $\mathrm{Mn}$ in Quercus cerris subsp. cerris.

The results of analysis of trace element values in plants collected at $1100 \mathrm{~m}$ are presented in Table 2. The table shows that $\mathrm{Ni}$ content was highest in Plantago holosteum $\left(1.806 \mu \mathrm{g} \mathrm{g}^{-1}\right)$, and the lowest in Rubus idaeus $\left(0.119 \mu \mathrm{g} \mathrm{g}^{-1}\right)$. In terms of $\mathrm{Zn}$ content, it was the highest in Fragaria vesca $\left(0.792 \mu \mathrm{g} \mathrm{g}^{-1}\right)$, and the lowest in Erica manipuliflora $\left(0.232 \mu \mathrm{g} \mathrm{g}^{-1}\right)$. Fe content was highest in Fragaria vesca $\left(5.720 \mu \mathrm{g} \mathrm{g}^{-1}\right)$, and the lowest in Abies nordmanniana subsp. equi-trojani $\left(0.618 \mu \mathrm{g} \mathrm{g}^{-1}\right)$. It was seen that $\mathrm{Pb}$ content was highest in Abies nordmanniana subsp. equi-trojani $\left(0.534 \mu \mathrm{g} \mathrm{g}^{-1}\right)$, and the lowest was in Origanum vulgare $\left(0.371 \mu \mathrm{g} \mathrm{g}^{-1}\right)$. The highest Mn content was observed in Quercus cerris subsp. cerris $\left(4.782 \mu \mathrm{g} \mathrm{g}^{-1}\right.$ ), while the lowest Mn content was in Celtis australis $\left(0.766 \mu \mathrm{g} \mathrm{g}^{-1}\right)$. At $1600 \mathrm{~m}$, Ni content was highest in Plantago holosteum, $\mathrm{Zn}$ and $\mathrm{Fe}$ were highest in Fragaria vesca, $\mathrm{Pb}$ was highest in Abies nordmanniana subsp. equi-trojani and Mn was highest in Quercus cerris subsp. cerris.

Sources of pollution that cause accumulation of various heavy metals have been reported by some researchers. For instance, $\mathrm{Pb}$ and $\mathrm{Zn}$ originate mainly from anthropogenic activities (Alfani et al., 2000; Blok, 2005; Oliva \& Rautio, 2005). The burning of coal and oil cause the production of $\mathrm{Cu}, \mathrm{Ni}$ and $\mathrm{Pb}$, and mining operations, steel works and the cement industry are major anthropogenic sources of Ni (Nriagu \& Pacyna, 1988). Plants have been reported to be highly affected by contamination of the soil by $\mathrm{Fe}$ and $\mathrm{Mn}$ in the Mediterranean climate zone, although airborne $\mathrm{Mn}$ originates mainly from soil (Loppi et al., 1999; Bargagli et al., 2003; Oliva \& Rautio, 2005). Fe originates both from anthropogenic and natural sources (Oliva \& Rautio, 2005).

Various researchers in different parts of the world, as well as in Turkey, investigated the accumulation of trace elements in plant parts. Some of those are given below for the purpose of comparison with our findings: Dijingova et al. (1995) (Cd: $0.10-31.20 \mu \mathrm{g} \mathrm{g}^{-}$ ${ }_{1}$, Ni : 0.50-4.9 $\mu \mathrm{g} \mathrm{g}^{-1}$, Zn: 7-302 $\mu \mathrm{g} \mathrm{g}^{-1}$, Fe: 100-283 $\mu \mathrm{g} \mathrm{g}^{-1}, \mathrm{~Pb}: 0.80-21.30 \mu \mathrm{g} \mathrm{g}^{-1}$, Mn: 44-405 $\mu \mathrm{g} \mathrm{g}^{-1}$ ), Baslar et al. (2003) (Ni: $0.88 \mu \mathrm{g} \mathrm{g}^{-1}$, Fe: $57.28 \mu \mathrm{g} \mathrm{g}^{-1}, \mathrm{~Pb}: 1.4 \mu \mathrm{g}$ $\mathrm{g}^{-1}$ ), Dogan et al. (2007) (Ni: $3.56 \mu \mathrm{g} \mathrm{g}^{-1}$, Fe: $486.35 \mu \mathrm{g} \mathrm{g}^{-1}, \mathrm{~Pb}: 4.59 \mu \mathrm{g} \mathrm{g}^{-1}$ ), Baslar et al. (2005) (Cd: $\left.1.7 \mu \mathrm{g} \mathrm{g}^{-1}, \mathrm{Zn}: 63.4 \mu \mathrm{g} \mathrm{g}{ }^{-1}, \mathrm{Fe}: 182.6 \mu \mathrm{g} \mathrm{g}^{-1}, \mathrm{~Pb}: 2.3 \mu \mathrm{g} \mathrm{g}^{-1}\right)$ and Kapusta et al. (2005) (Cd: $6.44 \mu \mathrm{g} \mathrm{g}^{-1}$, Pb: $\left.5.64 \mu \mathrm{g} \mathrm{g}^{-1}, \mathrm{Zn}: 304 \mu \mathrm{g} \mathrm{g}^{-1}\right)$.

Trace elements, which are an intrinsic part of nature, appear in the composition of plants. Bowen (1979) has reported the normal natural concentration intervals for land plants as Cd: $0.2-2.4 \mu \mathrm{g} \mathrm{g}^{-1}$, Ni: $1-5 \mu \mathrm{g} \mathrm{g}^{-1}, \mathrm{Zn}: 20-400 \mu \mathrm{g} \mathrm{g}^{-1}, \mathrm{Fe}: 70-700 \mu \mathrm{g} \mathrm{g}^{-1}, \mathrm{~Pb}$ : 1-13 $\mu \mathrm{g} \mathrm{g}^{-1}$, Mn: $20-700 \mu \mathrm{g} \mathrm{g}^{-1}$. Comparison of our results with these findings (Tables 1 and 2) clearly shows that our values are well below the accepted range. Hence, the 
area studied is free from the contamination of heavy metal pollution in terms of the trace elements investigated. The accumulation levels obtained are soil orientated.

Table 2. Trace element contents in plants growing in the Mt. Kazdagi ( $\mu g \mathrm{~g}-1$ dry weight) (1100m)

\begin{tabular}{|c|c|c|c|c|c|}
\hline Plant & $\mathbf{N i}$ & Zn & $\mathrm{Fe}$ & $\mathbf{P b}$ & Mn \\
\hline \multicolumn{6}{|c|}{ woody } \\
\hline Abies nordmanniana (Steven) & & & & & \\
\hline $\begin{array}{l}\text { Spach subsp. equi-trojani } \\
\text { (Asch. \& Sint. ex Boiss.) } \\
\text { Coode \& Cullen }\end{array}$ & 0.171 & 0.631 & 0.618 & 0.534 & 2.601 \\
\hline Castanea sativa Miller. & 0.214 & 0.704 & 1.902 & 0.414 & 2.246 \\
\hline Celtis australis $\mathrm{L}$. & 0.223 & 0.615 & 1.816 & 0.404 & 0.766 \\
\hline Erica manipuliflora Salisb. & 0.200 & 0.232 & 4.065 & 0.440 & 2.634 \\
\hline $\begin{array}{l}\text { Pinus nigra Arn. subsp. } \\
\text { pallasiana (Lamb) Holmboe }\end{array}$ & 0.237 & 0.486 & 1.272 & 0.417 & 2.623 \\
\hline $\begin{array}{l}\text { Quercus cerris L. subsp. } \\
\text { cerris }\end{array}$ & 0.187 & 0.321 & 1.833 & 0.420 & 4.782 \\
\hline Rubus idaeus L. & 0.119 & 0.393 & 1.045 & 0.470 & 3.820 \\
\hline \multicolumn{6}{|c|}{ herbaceous } \\
\hline $\begin{array}{l}\text { Dactylis glomerata L. subsp. } \\
\text { hispanica (Roth) Nymas }\end{array}$ & 0.201 & 0.384 & 0.997 & 0.460 & 1.154 \\
\hline $\begin{array}{l}\text { Dryopteris filix-mas (L.) } \\
\text { Schott }\end{array}$ & 0.179 & 0.510 & 0.812 & 0.434 & 0.892 \\
\hline Euphorbia sp. & 0.175 & 0.659 & 1.632 & 0.390 & 0.823 \\
\hline Fragaria vesca Coville & 0.678 & 0.792 & 5.720 & 0.512 & 3.352 \\
\hline Origanum vulgare L. & 0.314 & 0.625 & 5.165 & 0.371 & 1.339 \\
\hline Plantago holosteum L. & 1.806 & 0.732 & 4.823 & 0.519 & 2.474 \\
\hline Verbascum sp. & 0.161 & 0.377 & 1.472 & 0.445 & 1.466 \\
\hline Min.: & 0.119 & 0.232 & 0.618 & 0.371 & 0.766 \\
\hline Max. & 1.806 & 0.792 & 5.720 & 0.534 & 4.782 \\
\hline Mean: & $0.34 \pm 0.11$ & $0.53 \pm 0.04$ & $2.36 \pm 0.47$ & $0.44 \pm 0.01$ & $2.21 \pm 0.32$ \\
\hline
\end{tabular}

Baslar et al. (2009) have obtained the following results in a study they conducted on Mt. Honaz, which is another important mountain of the same region: The mean concentrations determined at $1000 \mathrm{~m}$ altitude ranged between 0.273 to $0.488,0.099$ to $0.488,0.306$ to $0.682,1.017$ to 3.744 , and 0.148 to 0.674 ( $\mu \mathrm{g} \mathrm{g}^{-1}$, dry weight), of $\mathrm{Pb}, \mathrm{Ni}$, $\mathrm{Zn}, \mathrm{Fe}$ and $\mathrm{Mn}$, respectively. At $1600 \mathrm{~m}$ altitude, the values ranged between 0.225 to $0.534,0.150$ to $0.842,0.234$ to $0.905,1.082$ to 3.864 and 0.023 to $0.982\left(\mu \mathrm{g} \mathrm{g}^{-1}\right.$, dry weight) of $\mathrm{Pb}, \mathrm{Ni}, \mathrm{Zn}, \mathrm{Fe}, \mathrm{Pb}$ and $\mathrm{Mn}$, respectively. No $\mathrm{Cd}$ was detected at either altitude. Additionally, Kula et al. (2010) have studied trace element concentrations of plants on Mt. Akdag and obtained the following results: The mean concentrations determined at $1000 \mathrm{~m}$ altitude ranged from 0.011 to $0.882,0.241$ to $0.714,0.532$ to 9.396, 0.329 to 0.487 , and 0.155 to 3.439 ( $\mu \mathrm{g} \mathrm{g}^{-1}$, dry weight), for $\mathrm{Ni}, \mathrm{Zn}, \mathrm{Fe}, \mathrm{Pb}$ and $\mathrm{Mn}$, respectively. At $1600 \mathrm{~m}$ altitude, the values ranged from 0.092 to $0.600,0.272$ to $0.834,1.130$ to $8.021,0.263$ to 0.889 and 0.076 to 0.508 ( $\mu \mathrm{g} \mathrm{g}^{-1}$, dry weight) for $\mathrm{Ni}, \mathrm{Zn}$, $\mathrm{Fe}, \mathrm{Pb}$ and $\mathrm{Mn}$, respectively. No $\mathrm{Cd}$ was detected at either altitude. The similarities of the results obtained from Mt. Honaz, Mt. Akdag and Mt. Kazdagi show the validity and credibility of all studies concerned.

In the statistical analysis, comparison of heavy metal pollution values of herbaceous and woody plants for $\mathrm{Ni}, \mathrm{Fe}$ and $\mathrm{Mn}$ was significant $(P<0.05)$, while it was not for $\mathrm{Pb}$ 
and $\mathrm{Zn}$ (Table 3). Kula et al. (2010) found the difference between the values of $\mathrm{Fe}, \mathrm{Pb}$ and Mn from herbaceous and woody plants of Mt. Akdag statistically significant, while Yildiz et al. (2010) found the values of Fe and Mn statistically significant in their work on Mt. Bozdag. When we compare our results with those of the above two studies, it can be concluded that the concentration of Fe, particularly, displays a statistically significant difference between herbaceous and woody plants of the area.

Table 3. Statistical analysis values of herbaceous and woody plants

\begin{tabular}{|c|c|c|c|c|c|c|c|c|c|c|}
\hline \multicolumn{11}{|c|}{ Independent Samples Test } \\
\hline & & \multicolumn{2}{|c|}{$\begin{array}{c}\text { Levene's Test for } \\
\text { Equality of Variances }\end{array}$} & \multicolumn{7}{|c|}{ t-test for Equality of Means } \\
\hline & & \multirow[b]{2}{*}{$\mathrm{F}$} & \multirow[b]{2}{*}{ Sig. } & \multirow[b]{2}{*}{$\mathrm{t}$} & \multirow[b]{2}{*}{$\mathrm{df}$} & \multirow[b]{2}{*}{ Sig. (2-tailed) } & \multirow{2}{*}{$\begin{array}{c}\text { Mean } \\
\text { Difference }\end{array}$} & \multirow{2}{*}{$\begin{array}{l}\text { Std. Error } \\
\text { Difference }\end{array}$} & \multicolumn{2}{|c|}{$\begin{array}{l}\text { 95\% Confidence } \\
\text { Interval of the } \\
\text { Difference }\end{array}$} \\
\hline & & & & & & & & & Lower & Upper \\
\hline $\mathrm{Ni}$ & $\begin{array}{l}\text { Equal variances } \\
\text { assumed } \\
\text { Equal variances } \\
\text { not assumed }\end{array}$ & 6,856 &, 015 & $\begin{array}{l}-1,564 \\
-1,501\end{array}$ & $\begin{array}{r}23 \\
11,139\end{array}$ & \begin{tabular}{|r|}
, 131 \\
, 161
\end{tabular} & $\begin{array}{l}-, 206519 \\
-, 206519\end{array}$ & $\begin{array}{l}\text {,132036 } \\
, 137598\end{array}$ & $\begin{array}{l}-, 479656 \\
-, 508911\end{array}$ & $\begin{array}{l}0666617 \\
, 095872\end{array}$ \\
\hline $\mathrm{Zn}$ & $\begin{array}{l}\text { Equal variances } \\
\text { assumed } \\
\text { Equal variances } \\
\text { not assumed }\end{array}$ &, 023 & ,881 & $\begin{array}{l}-, 516 \\
-, 514\end{array}$ & $\begin{array}{r}23 \\
22,433\end{array}$ & $\begin{array}{l}, 611 \\
, 612\end{array}$ & $\begin{array}{l}-, 032506 \\
-, 032506\end{array}$ & $\begin{array}{l}, 063001 \\
, 063201\end{array}$ & $\begin{array}{l}-, 162835 \\
-, 163430\end{array}$ & $\begin{array}{l}, 097822 \\
, 098417\end{array}$ \\
\hline $\mathrm{Fe}$ & $\begin{array}{l}\text { Equal variances } \\
\text { assumed } \\
\text { Equal variances } \\
\text { not assumed }\end{array}$ & 12,325 &, 002 & $\begin{array}{l}-1,502 \\
-1,454\end{array}$ & $\begin{array}{r}23 \\
13,522\end{array}$ & $\begin{array}{l}, 147 \\
, 169\end{array}$ & $\begin{array}{l}-1,163115 \\
-1,163115\end{array}$ & $\begin{array}{l}, 774471 \\
, 800065\end{array}$ & $\begin{array}{l}2,765230 \\
2,884797\end{array}$ & $\begin{array}{l}, 438999 \\
, 558566\end{array}$ \\
\hline $\mathrm{Pb}$ & $\begin{array}{l}\text { Equal variances } \\
\text { assumed } \\
\text { Equal variances } \\
\text { not assumed }\end{array}$ & ,331 &, 570 & $\begin{array}{l}, 842 \\
, 846\end{array}$ & $\begin{array}{r}23 \\
23,000\end{array}$ & $\begin{array}{l}, 408 \\
, 407\end{array}$ & $\begin{array}{l}, 019756 \\
, 019756\end{array}$ & $\begin{array}{l}, 023450 \\
, 023366\end{array}$ & $\begin{array}{l}-, 028753 \\
-, 028579\end{array}$ & $\begin{array}{l}, 068266 \\
, 068092\end{array}$ \\
\hline $\mathrm{Mn}$ & $\begin{array}{l}\text { Equal variances } \\
\text { assumed } \\
\text { Equal variances } \\
\text { not assumed }\end{array}$ & 4,524 &, 044 & $\begin{array}{l}1,460 \\
1,487\end{array}$ & $\begin{array}{r}23 \\
20,271\end{array}$ & $\begin{array}{l}, 158 \\
, 152\end{array}$ & $\begin{array}{l}, 701558 \\
, 701558\end{array}$ & $\begin{array}{l}, 480539 \\
, 471746\end{array}$ & $\begin{array}{l}-, 292513 \\
-, 281643\end{array}$ & $\begin{array}{l}1,695629 \\
1,684759\end{array}$ \\
\hline
\end{tabular}

In the present study, the plants used as biomonitors to investigate the levels of the trace elements $\mathrm{Cd}, \mathrm{Ni}, \mathrm{Zn}, \mathrm{Fe}, \mathrm{Pb}$ and $\mathrm{Mn}\left(\mu \mathrm{g} \mathrm{g}^{-1}\right.$, dry weight), were sampled with 25 different species at two different heights $(600 \mathrm{~m}$ and $1100 \mathrm{~m})$ on Mt. Kazdagi. The values of the trace elements we obtained were below the values obtained from control samples of other studies of clean areas, and therefore low values are concluded to be soil orientated. We are convinced that this study will contribute to future studies on pollution.

\section{REFERENCES}

[1] Akguc, N., Ozyigit, I.I., Yasar, U., Leblebici, Z., Yarci, C. (2010): Use of Pyracantha coccinea Roem. as a possible biomonitor for the selected heavy metals. - International Journal of Environmental Science and Technology 7 (3): 427-434.

[2] Aksoy, A., Sahin, U., Duman, F. (2000): Robinia pseudo-acacia L. as a posssible biomonitor of heavy metal pollution in Kayseri. - Turkish Journal of Botany 24: 279-284.

[3] Alfani, A., Baldantoni, D., Maisto, G., Bartoli, A., Virzo De Santo, A. (2000): Temporal and spatial variation in C, N, S and element contents in the leaves of Quercus ilex with in the urban area of Naples. - Environmental Pollution 109 (1): 119-129. 
[4] Anonymous (1996): Analysis of plant tissue: Wet digestion. In: Analytical methods for atomic absorption spectroscopy. Perkin Elmer, Inc., USA, pp 141-143.

[5] Bargagli, R (1998): Trace Elements in Terrestrial Plants: An Ecophysiological Approach to Biomonitoring and Biorecovery. Springer-Verlag, New York.

[6] Bargagli, R., Monaci, F., Agaorelli, C. (2003): Oak leaves as accumulators of airborne elements in an area with geochemical and geothermal anomalies. - Environmental Pollution 124 (2): 321-329.

[7] Baslar, S., Dogan, Y., Bag, H., Elci, A. (2003): Trace element biomonitoring by needles of Pinus brutia from Western Anatolia. - Fresenius Environmental Bulletin 12 (5): 450453.

[8] Baslar, S., Dogan, Y., Yenil, N., Karagoz, S., Bag, H. (2005): Trace element biomonitoring by leaves of Populus nigra L. from Western Anatolia, Turkey. - Journal of Environmental Biology 26 (4): 665-668.

[9] Baslar, S., Kula, I., Dogan, Y., Yildiz, D., Ay, G. (2009): A Study of Trace Element Contents in Plants Growing at Honaz Dagi-Denizli, Turkey. - Ekoloji 18: 1-7.

[10] Baycu, G., Tolunay, D., Ozden, H., Gunebakan, S. (2006): Ecophysiological and seasonal variations in $\mathrm{Cd}, \mathrm{Pb}, \mathrm{Zn}$ and $\mathrm{Ni}$ concentrations in the leaves urban deciduous trees in Istanbul. - Environmental Pollution 143 (3): 545-554.

[11] Blok, J. (2005): Environmental exposure of road borders to zinc. - Science of the Total Environment 348 (1-3): 173-190.

[12] Bowen, H.J.M. (1979): Environmental chemistry of the elements. Academic Press, London, New York.

[13] Calzoni, G.L., Antognoni, F., Pari, E., Fonti, P., Gnes, A., Speranza, A. (2007): Active biomonitoring of heavy metal pollution using Rosa rugosa plants. - Environmental Pollution 149 (2): 239-245.

[14] Cayir, A., Coskun, M., Coskun, M. (2008): Concentrations of Some Elements in the Bioindicator Organism Cladonia rangiformis Collected at the Vicinity of Canakkale. Ekoloji 18: 7-13.

[15] Davis, P.H. (Ed.) (1965-1985): Flora of Turkey and the East Aegean Islands. Vols. 1-9, Edinburg University Press, Edinburg.

[16] Davis, P.H., Mill, R.R., Tan, K. (1988): Flora of Turkey and the East Aegean Islands (Supplement). Vol. 10, Edinburg University Press, Edinburg.

[17] Dijingova, R., Wagner, G., Peshev, D. (1995): Heavy Metal Distribution in Bulgaria using Populus nigra italica as a Biomonitor. - Science of the Total Environment 172 (2): 151-158.

[18] Dogan, Y. (2012): Traditionally used wild edible greens in the Aegean Region of Turkey. - Acta Societatis Botanicorum Poloniae 81 (4): 245-255.

[19] Dogan, Y., Durkan, N., Baslar, S. (2007): Trace element pollution biomonitoring using the bark of Pinus brutia in the Western Anatolian part of Turkey. - Trace Elements and Electrolytes 24 (5): 146-150.

[20] Dogan, Y., Ugulu, I., Baslar, S. (2010): Turkish Red Pine as a Biomonitor: A Comparative Study of the Accumulation of Trace Elements in the Needles and Bark. Ekoloji 19: 88-96.

[21] Dogan, Y., Ugulu, I., Durkan, N. (2013). Wild Edible Plants Sold in the Local Markets of Izmir. - Pakistan Journal of Botany 45 (S1): 177-184.

[22] Durkan, N., Ugulu, I., Unver, M.C., Dogan, Y., Baslar, S. (2011). Concentrations of trace elements aluminum, boron, cobalt and tin in various wild edible mushroom species from Buyuk Menderes River Basin of Turkey by ICP-OES. - Trace Elements and Electrolytes 28 (4): 242-248.

[23] Elekes, C.C., Dumitriu, I., Busuioc, G., Iliescu, N.S. (2010): The appreciation of mineral element accumulation level in some herbaceous plants species by ICP-AES method. Environmental Science and Pollution Research 17: 1230-1236. 
[24] El-Hasan, T., Al-Omari, H., Jiries, A., Al-Nasir, F. (2002): Cypress tree (Cupressus sempervirens L.) bark as an indicator for heavy metal pollution in the atmosphere of Amman City, Jordan. - Environment International 28 (6): 513-519.

[25] Guner, A., Ozhatay, N., Ekim, T., Baser, K.H. (2001): Flora of Turkey and the East Aegean Islands (Supplement II). Vol. 11, Edinburg University Press, Edinburg.

[26] Huseyinova, R., Kutbay, H.G., Bilgin, A., Kilic, D., Horuz, A., Kirmanoglu, C. (2009): Sulphur and Some Heavy Metal Contents in Foliage of Corylus avellana and Some Roadside Native Plants in Ordu Province, Turkey. - Ekoloji 18 (70): 10-16.

[27] Kapusta, P., Szarek-Lukaszewska, G., Godzik, B. (2006): Spatio-temporal variation of element accumulation by Moehringia trinervia in a polluted forest ecosystem (South Poland). - Environmental Pollution 143 (2): 285-293.

[28] Karaca, F., Alagha, O., Erturk, F. (2005): Statistical characterization of atmospheric PM10 and PM2.5 concentrations at a non-impacted suburban site of Istanbul, Turkey. Chemosphere 59: 1183-1190.

[29] Kaya, G., Yaman, M. (2008): Trace Metal Concentrations in Cupressaceae Leaves as Biomonitors of Environmental Pollution. - Trace Elements and Electrolytes 25 (3): 156164.

[30] Kula, I., Yıldiz, D., Dogan, Y., Ay, G., Baslar, S. (2010): Trace Element Contents in Plants Growing at Akdag, Denizli. - Biotechnology and Biotechnological Equipment 24 (1): 1587-1591.

[31] Loppi, S., Giomerelli, B., Bargagli, R. (1999): Lichens and mosses as biomonitors of trace elements in a geothermal area (Mt. Amiata, central Italy). - Cryptogamie Mycologie 20 (2): 119-126.

[32] Mertens, J., Luyssaert, S., Verheyen, K. (2005): Use and abuse of trace metal concentrations in plant tissue for biomonitoring and phytoextraction. - Environmental Pollution 138 (1): 1-4.

[33] Ng, O-H., Tan, B.C., Obbard, J.P. (2005): Lichens as Bioindicators of Atmospheric Heavy Metal Pollution in Singapore. - Environmental Monitoring and Assessment 123: 63-74.

[34] Nriagu, J.O., Pacyna, J. (1988): Quantitative assessment of worldwide contamination of air, water and soils by trace metals. - Nature 333: 134-139.

[35] Oliva, S.R., Rautio, P. (2005): Spatiotemporal patterns in foliar element concentrations in Ficus microcarpa L. f. growing in an urban area: implications for biomonitoring studies. Ecological Indicators 5 (2): 97-107.

[36] Onder, S., Dursun, S., Gezgin, S., Demirbas, A. (2007): Determination of Heavy Metal Pollution in Grass and Soil of City Centre Green Areas (Konya, Turkey). - Polish Journal of Environmental Studies 16 (1): 145-154.

[37] Osma, E., Ozyigit, I.I., Leblebici, Z., Demir, G., Serin, M. (2012): Determination of heavy metal concentrations in tomato (Lycopersicon esculentum Miller) grown in different station types. - Romanian Biotechnological Letters 17 (1): 6962-6974.

[38] Ozturk, M., Yucel, E., Gucel, S., Sakcali, S., Aksoy, A. (2008): Plants as Biomonitors of Trace Elements Pollution in Soil. In: Prasad MNV (ed), Trace Elements as Contaminants and Nutrients: Consequences in Ecosystems and Human Health, John Wiley \& Sons, Inc., Hoboken, NJ, 721-742.

[39] Prasad, M.N.V., Freitas, H.M.O. (2003): Metal hyperaccumulation in plants-Biodiversity prospecting for phytoremediation technology. Electronic Journal of Biotechnology 6 (3): $285-321$.

[40] Satil, F. (2008): Threatening Factors on Plant Diversity of Kazdagi (Ida Mountain) National Park in Turkey and Suggestions for Conservation. - Biotechnology and Biotechnological Equipment 23: 208-211.

[41] Singh, M., Goel, P., Singh, A. (2005): Biomonitoring of lead in atmospheric environment of an urban center of the Ganga Plain, India. - Environmental Monitoring and Assessment 107: 101-114.

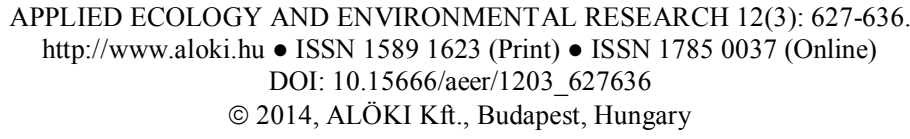


[42] Smodis, B., Pignata, M.L., Saiki, M. (2004): Validation and application of plants as biomonitors of trace element atmospheric pollution - A co-ordinated effort in 14 countries. - Journal of Atmospheric Chemistry 49 (1-3): 3-13.

[43] Szczepaniak, K., Biziuk, M. (2003): Aspects of the biomonitoring studies using mosses and lichens as indicators of metal pollution. - Environmental Research 93 (3): 221-230.

[44] Szyczewski, P., Siepak, J., Niedzielski, P., Sobczynski, T. (2009): Research on Heavy Metals in Poland. - Polish Journal of Environmental Studies 18 (5): 755-768.

[45] Ugulu, I. (2012). Fidelity level and knowledge of medicinal plants used to make Therapeutic Turkish Baths. - Studies on Ethno-Medicine 6 (1): 1-9.

[46] Ugulu, I., Aydin, H., Yorek, N., Dogan, Y. (2008): The Impact of Endemism Concept on Environmental Attitudes of Secondary School Students. - Natura Montenegrina 7 (3): $165-173$.

[47] Ugulu, I., Dogan, Y., Baslar, S., Varol, O., (2012): Biomonitoring of trace element accumulation in plants growing at Murat Mountain. - International Journal of Environmental Science and Technology 9: 527-534.

[48] Yasar, U., Ozyigit, I.I., Demir, G., Y1lmaz, Y.Z. (2012a): Determination of hair iron levels of healthy female high school students with AAS in the Pendik District, IstanbulTurkey. - Fresenius Environmental Bulletin 21 (9): 2644-2648.

[49] Yasar, U., Ozyigit, I.I., Yalcin, I.E., Doğan, I., Demir, G. (2012b): Determination of some heavy metals and mineral nutrients of bay tree (Laurus nobilis L.) in Bartin City, Turkey. - Pakistan Journal of Botany 44(SI): 81-89.

[50] Yilmaz, R., Sakcali, S., Yarci, C., Aksoy, A., Ozturk, M. (2006): Use of Aesculus hippocastanum L. as a biomonitor of heavy metal pollution. - Pakistan Journal of Botany 38 (5): 1519-1527.

[51] Yilmaz, S., Zengin, M. (2004): Monitoring environmental pollution in Erzurum by chemical analysis of Scots pine (Pinus sylvestris L.) needles. - Environment International 29 (8): 1041-1047.

[52] Zechmeister, H.G. (1995): Correlation between altitude and heavy metal deposition in the Alps. - Environmental Pollution 89 (1): 73-80.

[53] Yildiz, D., Kula, I., Ay, G., Baslar, S., Dogan, Y. (2010): Determination of Trace Elements in the Plants of Mt. Bozdag, Izmir, Turkey. - Archives of Biological Sciences 62 (3): 731-738. 